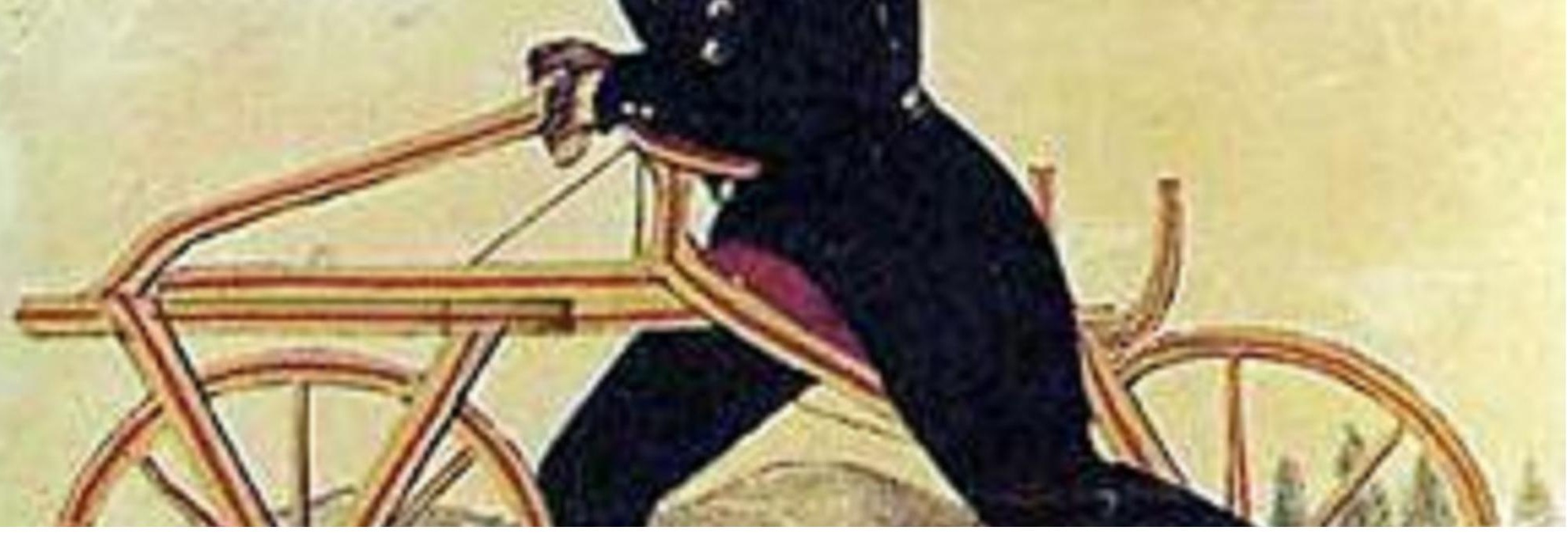

\title{
A Two-Path Process Model of Invention: Conclusions from six years of Research with independent Inventors
}

$\begin{aligned} \text { Authors: } & \text { Harald A. Mieg } \\ \text { Submitted: } & \text { 6. February } 2020 \\ \text { Published: } & 8 \text {. February } 2020 \\ \text { Volume: } & 7 \\ \text { Issue: } & 1 \\ \text { Affiliation: } & \text { Humboldt-Universität zu Berlin, Germany } \\ \text { Languages: } & \text { English } \\ \text { Keywords: } & \text { Inventor; Invention; Patents; Creativity; Innovation } \\ \text { Categories: } & \text { Humanities, Social Sciences and Law, Life Sciences } \\ \text { DOI: } & \text { 10.17160/josha.7.1.629 }\end{aligned}$

Abstract:

This paper introduces a two-path model of the invention that comprises two processes: a long-term, ideadriven path, and a short-term, problem-solving path. The model focuses on individual inventors and includes the success factors for the invention that are known from the literature. The model resumes the line of research in independent inventors and responses to five open issues that are central to current research on inventors: the role of creativity; the high level of persistence amongst inventors; the role of knowledge; the permanent transgression of domains by inventors; success criteria. The paper contains an extended review of the state of research on inventors and presents current approaches to explaining inventiveness. A core assumption of the paper is to understand the invention in the context of long-term technological development.

\section{JOSHA Jouma a s semenes Humanities and Arts}




\title{
A Two-Path Process Model of Invention: Conclusions from six years of research with independent inventors ${ }^{1}$
}

\author{
Harald A. Mieg, Katrin M. Wolf, Christian Hofmann \& Stephan Bedenk
}

Humboldt-Universität zu Berlin

September 2010

contact: harald.mieg@hu-berlin.de

\begin{abstract}
This paper introduces a two-path model of invention that comprises two processes: a long-term, idea-driven path, and a short-term, problem-solving path. The model focuses on individual inventors and includes the success factors for invention that are known from the literature. The model resumes the line of research in independent inventors and responses to five open issues that are central to current research on inventors: the role of creativity; the high level of persistence amongst inventors; the role of knowledge; the permanent transgression of domains by inventors; success criteria. The paper contains an extended review of the state of research on inventors and presents current approaches to explaining inventiveness. A core assumption of the paper is to understand invention in the context of long-term technological development.
\end{abstract}

Keywords: Inventor; Invention; Patents; Creativity; Innovation

\footnotetext{
${ }^{1}$ Postscript July 2019: This paper presents the conclusions from six years of research with independent German inventors. The paper was written by Harald Mieg in 2010 and was intended as a team publication: Katrin Wolf conducted most of the empirical studies, Christian Hoffmann organized the contact with inventors, Stephan Bedenk helped finish the papers. Research was funded by the Hans Sauer Foundation (Munich) from 2004 to 2010. Following the (abrupt) end of funding, the research group dissolved; consequently, there was no time to discuss or submit the proposed paper. Unfortunately, the line of research also came to an end.
} 


\section{Introduction}

The process of invention can be conceived of in two different ways, as a problemsolving process or as driven by a technological idea. We find evidence for both views. On the one hand, Henderson (2004a) describes inventors as expert problem solvers. In the same vein, the invention methodology TRIZ became the basis for teaching inventors problem-solving skills in the former Soviet Union (cf. Orloff, 2006). On the other hand, Weber, analyzing the case of the Wright Brothers, shows the structurizing impact of the overall idea of achieving powered and sustained heavier-than-air human flight (1992a; 2006). Similarly, in-depth interviews with successful inventors underline the influence of guiding ideas for the process of invention (e.g., Brown, 1988). Therefore, we propose a two-path process model that integrates both process aspects-problem solving as well as guidance though a technological idea.

Inventors are still the 'black box' of the innovation process. We know that teamwork is indispensable in today's $R \& D$, reducing the importance of the individual inventor (West, 2002). However, we also know that, very often, a great share of a firm's patents-sometimes up to half of the patents portfolio-may be held by a single inventor (Narin and Breitzman, 1995). Invention is generally regarded as a "distinct form of creativity" (Lemelson-MIT Program, 2003, p. 12). However, creativity studies with real inventors are rare.

This paper reviews the literature on inventors and provides a model that integrates the common findings on success factors and the process of invention. In particular, it resumes an earlier line of discussion on independent vs. employed inventors (Dahlin et al., 2004; Lettl et al., 2009). The proposed model is valid both for independent inventors and top inventors employed within a company structure.

\section{Review of Research on Inventors}

This chapter first presents key findings (section 1.1) from research on inventors; secondly research desiderata, that is, open issues that any theory on inventors should answer (section 1.2). The current theoretical approaches will be introduced in chapter two.

\subsection{Key Findings}

The key findings are presented in three sections, starting with the most recent and notable large studies on inventors that represent more general approaches (1.1.1). The subsequent sections cover factors regarding the person of an inventor (1.1.2) and the process of invention (1.1.3). Figure 1 show how the key findings will be translated into research desiderata. 


\begin{tabular}{|c|c|}
\hline Key findings (1.1) & Research desiderata (1.2) \\
\hline $\begin{array}{l}\text { General } \\
\text { - Independent inventors } \\
\text { - „Architecture of cognition“ } \\
\text { - European PatVal Study }\end{array}$ & $\begin{array}{l}\text { Inventors in context } \\
\text { Transgression of domains! (D) } \\
\text { Role of knowledge ? (C) }\end{array}$ \\
\hline $\begin{array}{l}\text { Person } \\
\text { - Creativity } \\
\text { - Productivity } \\
\text { - Personality }\end{array}$ & $\begin{array}{l}\text { Role of creativity ? (A) } \\
\text { Sucess criterion ? (E) } \\
\text { Persistence ! (B) }\end{array}$ \\
\hline $\begin{array}{l}\text { Process } \\
\text { - Heuristics } \\
\text { - Cybernetic aspects }\end{array}$ & Process model \\
\hline
\end{tabular}

Figure 1: Key findings (section 1.1) and their translation into research desiderata (section 1.2)

\subsubsection{General}

Research on inventors is scarce. One of the earliest systematic studies on inventors was by Rossman (1930/1964). That study collected statistical data demonstrating, for instance, the often underestimated contribution of independent inventors to the national stock of innovations. Fortunately, some more recent studies focused on independent inventors. Dahlin et al. (2004), studying independent inventors in the tennis racket industry, found independent inventors to be a heterogeneous group, "overrepresented both among the most impactful and the least impactful patents." Lettl et al. (2009), analyzing patents in the medical equipment industry, revealed that technological specialization "pays off more" for independent inventors than for employed inventors.

Any deeper understanding requires research on inventors and their organizational contexts, or: inventors in context. Since the time of Rossman (1930/1964), the share in patents by independent inventors has constantly decreased. Whereas independent inventors accounted for about half of all patents in 1930 in the USA and other industrialized countries, in 2010 only 13.2 percent of US patents were awarded to independent inventors (compared with approximately 17 percent in Germany). The 'Edison-type' of inventor seems to have disappeared. In recent years, there were two milestones in the general research on inventors, the 2003 LemelsonMIT workshop on invention, and PatVal-EU, a European study from 2003-2004 on the value of patents.

The goal of the 2003 MIT workshop was "to define what was known and outline what needed to be known concerning the fundamental nature of the inventive mind and the fundamental processes of invention" (Lemelson-MIT Program, 2003, p. 3). The workshop brought together scholars and inventors and provided an "interior 
view" of the process of invention. The workshop report is a rich scientific source of insights on invention-related cognition. It defined the standard set of phenomena that need to be explained by any theory on human invention. Two results might be highlighted. Firstly, the productive role of failure. Inventors are accustomed to failure, and try to learn from it. Secondly, invention requires "boundary transgressions." Inventors draw upon knowledge and resources from any available source, "irrespective of disciplinary or other boundaries" (p. 9). David Perkins, who chaired the workshop, used the term "transgressive cognition," to summarize the workshop and point to the particular characteristic of invention: "the cognitive processes of inventive thinking are full of boundary transgressions - they cross boundaries all the time in various ways" (Perkins, 2004, p. 40).

The second milestone was the so-called "PatVal" study on the value of European patents (Giuri et al., 2007). PatVal mainly comprised a survey conducted from May 2003 to January 2004. A questionnaire was submitted to the inventors of 27,531 patents granted by the European Patent Office between 1993 and 1997. The inventors returned 9,216 questionnaires covering 9,017 patents from France, Germany, Italy, the Netherlands, Spain and the United Kingdom. The PatVal study demonstrated the importance of large enterprises and cooperation in invention; only one-third of the PatVal patents involved a single inventor (p. 1114). Giuri et al. (2007) even concluded that "the available information in the patent files severely underestimates the actual extent of collaboration in the development of patents." (p. 1122) Moreover PatVal highlighted the role of education and specialized knowledge: $76.9 \%$ of inventors had a post-graduate education and $26 \%$ a $\mathrm{PhD}$ (p. 1111). It was concluded that customers are the most important source of knowledge for a particular patented invention (Giuri et al., 2007).

\subsubsection{Person}

The following section addresses three topics. The first is creativity, as invention is always linked to creativity, invention being regarded as a "distinct form of creativity" (Lemelson-MIT Program, 2003, p. 12). Secondly, we must deal with research on the skewed performance distribution, in which a few highly productive inventors hold disproportionately large numbers of patents. Thirdly, we will examine research on the personalities of inventors. Here, we will point to one of the most astonishing, and controversial, characteristics of inventors - their persistence.

\section{Creativity}

In general, psychological research on inventors is embedded in or derived from creativity research (cf. Mumford, 2003; Weisberg, 2006a\&b). A classical interpretation of creativity refers to "divergent thinking" (Guilford, 1967). Divergent thinking consists of opening paths and looking in different directions when solving a problem. Its opposite is convergent thinking: successively narrowing 
the search space. A simple measure of creativity as divergent thinking is the number of ideas produced per interval of time spent working at a problem (e.g., King et al., 1996; McCrae, 1987). In innovation research, Kirton (1976) argued similarly to Guildford, discriminating between adaptors vs. innovators. Innovators pursue new ideas and products, whilst adaptors fit them to current processes.

Applying this understanding of creativity, we would expect inventors to be innovators who tend towards divergent thinking. We find this interpretation, for instance, with Huber (1998, p. 238-9) who makes reference to Simonton (1988) and (Kirton, 1994), and distinguishes between an "analytical-adaptor type" and an "intuitive-innovator type," the first being characterized by convergent thinking, the second by divergent thinking. According to Huber (1998), top inventors are intuitive innovators. However, Wolf and Mieg (2010) conducted research on complex problem solving among inventors. In their experimental setting the correlation between an inventor's success and divergent thinking was non-significant. Similarly, the creativity researcher Weisberg sees little empirical evidence for the contribution of divergent thinking to the explanation of creativity (2006a, p. 589).

\section{Productivity}

Research on inventor productivity most often refers to studies with scientists, showing that the productivity distribution in science is skewed (e.g., Lotka, 1926; Price, 1963; Simonton, 1988). Only a few inventors display high productivity, and most of them have comparatively low productivity (e.g., Ernst et al., 2000; Huber, 1998; Narin and Breitzman, 1995). In a survey by Huber (1998), the top $10 \%$ of inventors produced over $40 \%$ of all patents (p. 233). In an even more extreme example, Narin and Breitzman (1995) found that in the four semiconductor companies from Japan and the USA, the most productive inventor in each company accounted for more than half of its patents (p. 511). Highly productive inventors, therefore, appear to be rare.

As reported, research on independent inventors (Dahlin et al., 2004; Lettl et al., 2009) indicates that independent inventors form a heterogeneous group of either very successful or unsuccessful inventors. In a study on independent inventors holding patents in Berlin (Mieg et al., 2010), about two thirds of the independent inventors received insufficient or zero revenue from their invention, with a net return of less than 5000 Euros/year. This clearly brings us to the question of how we should assess the success of inventors. Several studies have attempted to define impact- or market values for inventions (e.g., Giuri et al., 2007). Wolf and Mieg (2010) proposed invention efficiency (IE) for relating the marketed value of patents to the number of patents. Using this measure, we find independent inventors who are fairly inefficient, producing large numbers of patents that are never marketed.

\section{Personality}


A positive self-image seems to be a supporting factor in technological innovation (Hellström et al., 2002). Henderson (2004b) emphasizes the role of emotional experience for inventors, for instance "affective pleasure in self-expression." In general, as Henderson's studies (2004a\&b) reveal, inventors are intrinsically motivated, striving for mastery and pleasure - a characteristic supported by the PatVal study (Giuri et al., 2007). To ascertain more about personal factors among inventors, Braun et al. (2009) tested inventors using standard psycho-diagnostic tools, covering the "big five" personality factors, risk behavior, efficacy, and selfconcepts. Unfortunately, their results showed no strong confirmation of any of the personality-based assumptions concerning risk behavior, efficacy, or self-concepts. Although inventors in general showed somewhat elevated scores for openness to experience, top inventors did not. The only robust result concerned the emotional stability of inventors, as they displayed very low scores for neuroticism (cf. Braun et al., 2009). This trait appears to be a necessity for tolerating the high levels of frustration involved in inventing. Nonetheless, it is insufficient to explain inventiveness.

Inventors show a very high degree of persistence or perseverance in pursuing their idea (cf., e.g., Lemelson-MIT Program, 2003; Weber, 1996). Inventors say, for instance: "An inventor may try hundreds of things that don't work and that gives most people the impression that he is somewhat crazy" (Brown, 1988, p. 85), or: "To be an inventor you not only must have the idea, but also must believe in it so strongly that you're not going to take 'no' for an answer" (p. 289). In organizations, this persistence may lead to delayed project abandonment (Zayer, 2007) and the risk of increased development costs. However, resistance to an invention project may even strengthen the project and increase the success rate (Kriegesmann et al., 2007). In cases that seem doomed to failure, Åstebro et al. (2007) attribute inventors' persistence to their greater optimism and even overconfidence. Braun et al. (2009) point to an increased frustration tolerance based on high emotional stability. Mieg (2010) emphasizes the cognitive aspect of persistence in inventors a cognitive focus that allows for integrating any kind of information that might be relevant to realizing the idea in focus. 


\subsubsection{Process}

In general, any invention requires resources, both financial and human (i.e., qualified personnel). Therefore, invention is most often considered as embedded in an innovation process in an organizational setting. Thus, invention is seen as a result of teamwork (e.g., West, 2002; Giuri et al., 2007). In this section, however, we will focus on process characteristics of invention, given the necessary resources and organizational requirements. We start with heuristics, the classical cognitive process description of invention, and then turn to cybernetic aspects of invention such as recursivity and metacognition.

\section{Heuristics}

The word "heuristics" originates from Greek and fits perfectly with our context of inventive cognition, as "the art of discovery." Duncker (1935) introduced the concept of heuristics into psychology (cf. also Newell, 1985). Newell and Simon (1972) popularized heuristics within the scientific community, describing them as mental procedures that explain human problem-solving behavior. Since then, a heuristic has come to mean a rule of thumb for efficient and effective problem solving; heuristics are "methods of solution which, in contrast to an algorithm, do not guarantee that a solution will be found" (Mieg, 1993, p. 31). In several studies, the psychologist Weber tried to determine the set of heuristics that are typical of invention (Weber et al., 1990; Weber, 1992b, 1996). The three most frequently revealed heuristics are: (i) trial and error; (ii) analogy, i.e., importing solution ideas or patterns from foreign domains; and (iii) sub-goaling, i.e., splitting up a problem into a set or system of sub-problems that might be handled independently (cf. also Lemelson-MIT Program, 2003). However, despite a number of attempts, no such set of heuristics has been found sufficient for invention, or refined to inventions/inventors (Mieg, 2010).

\section{Cybernetic aspects}

Whilst heuristics refer to the art of discovery, cybernetics refer to the control of processes such as discovery. We want to introduce two such cybernetic aspects, recursiveness and metacognition. We start with prototypes as a practical aspect of the invention process.

Artur Fischer, the German inventor with the most patents, wrote about the process of invention (Fischer, 1987). He understood the invention process as a sort of problem solving backed by patenting. The way he described his inventions, such as the flashlight cube or the nylon plug, can be interpreted as a constant reworking of prototypes. Prototypes are first models of the invention that demonstrate the principle and allow for an understanding of the technical and physical relations and problems of an invention. 
On a more abstracted level, Arthur (2009) points out that invention is a recursive process at several levels. At the general level of technological development, any invention is a recombination and adaptive refinement of existing technologies and principles - in the way that innovation was already understood by Schumpeter (1934/1911). Thus, in general, several inventors or teams are working and reworking similar problems at the same time and may learn from each other to handle the problem technologically. At the level of particular inventions, any invention process is recursive in that it repeats the entailed specific sub-problems until each of them can be physically and practically mastered. Recursiveness is also at the heart of what Gardner (1997) called leveraging by extraordinary minds: to repeatedly use a specific, excellent skill in order to overcome the lack of knowledge or skills in other domains. For instance, the Montgolfier brothers intensively capitalized the know-how of paper manufacturing - their family's business - for their inventions, including balloon-flight.

A further cybernetic aspect is metacognition. This refers to higher-level principles and procedure to steer and control cognition, including the application of heuristics. Metacognition is thus knowledge about one's own knowledge; it is generally considered as a core cognitive characteristic of top experts (Feltovich et al., 2006, p. 55). In a study with inventors, Wolf and Mieg (2010) found that a metacognitive measure can best explain performance differences among expert inventors, namely the deliberate control of divergent and convergent thinking. In their experimental setting, this variable identified the top $10 \%$ performers. In inventors, the controlled trade-off between divergent and convergent thinking means both sparkling creativity and goal-oriented, systematic control.

\subsection{Five theory criteria: What is to be explained in invention?}

Any theory on invention that takes into account individual inventors has to clarify some aspects of the invention process or explain some specific phenomena in inventors, respectively. Figure 1 shows these research desiderata and their derivation from the state of research. The five desiderata comprise three open issues indicated by question marks (knowledge, creativity, success) and two phenomena indicated by exclamation marks (transgression, persistence). Figure 1 also contains two further postulations that here do not have the status of desiderata, namely inventors in context and a process model. A process model is a wish that might not be feasible or which can only be realized in a normative way. Furthermore, to view inventors in context is common in innovation theories, however, it might be too rigid a restriction for a theory on inventors. There are possible theories of inventors that lack any contextual aspects. The five remaining research desiderata are as follows.

A) Open issue: Role of creativity?

What is the role of creativity in invention? Are inventors super-creative? Is there a specific invention creativity? 
B) Phenomenon to explain: Persistence!

How can the extraordinary persistence of inventors be explained? Inventors usually persist with ideas even then the intended solutions seem rather unsound from a technological perspective. If inventors are super-creative, why do they not switch technological ideas more often?

C) Open issue: Role of knowledge?

What is the role of technological knowledge in invention? What types and domains of knowledge and skills are necessary to become a professional inventor?

D) Phenomenon to explain: Transgression of domains!

Inventors persistently transgress domains. How can we explain this fact? If we think of invention as knowledge-based professional work (e.g., Ericsson et al., 2006), then professional inventors should be highly specialized and boundary transgression unlikely.

E) Open issue: Success

How can we measure the success of inventors? Patents are the most widely used success criterion. However, there are arguments to better integrate the market success of an invention, the technological impact and/or the general creative output of an inventor into the success criterion.

Figure 2 (upper panel) provides a classification of the five research desiderata. We have two general issues (the role of creativity and knowledge) and two inventorspecific phenomena (transgression of domains, persistence). Each of the phenomena contradicts, to some extent, one of the general issues and fits the other one. For instance, the high persistence of inventors does not fit the idea of creativity in the form of divergent thinking; under the latter, we would expect inventors to shift their attention to other topics when difficult problems arise. The success criterion adds to the set of any other criteria. Figure 2 (bottom panel) also contains the positioning of current approaches that will be presented in the next chapter. 

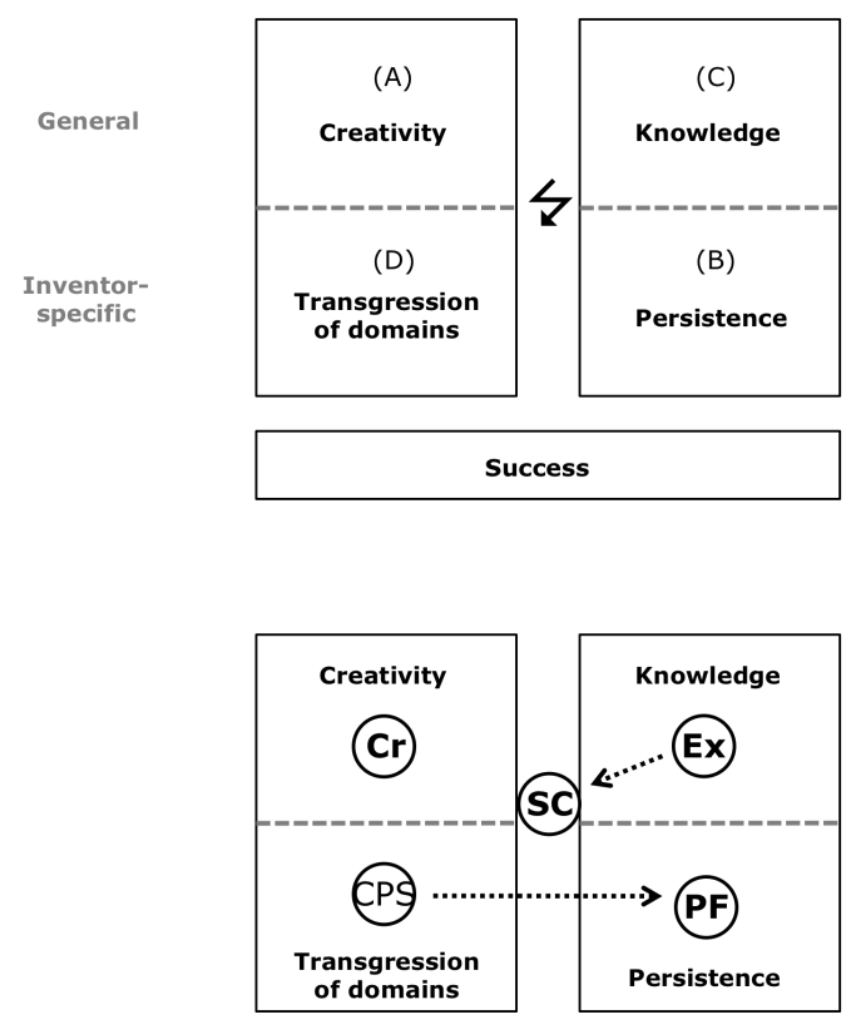

(Ent) Success

Figure 2: A system of five desiderata for research on inventors (top) and the positioning of current approaches (bottom). Approaches: Cr: creativity; CPS: complex problem solving; Ex: expertise; Ent: entrepreneurship; PF: possibility filter; SC: situated cognition

\section{Current Approaches}

In the following, we present six different approaches that have a certain focus on the individual inventor. Each approach will be discussed with regard to the five explanatory criteria.

\subsection{Creativity (cf. Fig. 2: Cr)}

Creativity is a multifaceted term. In science, it can be both a phenomenon to be explained (creativity as explanandum) and a psychological factor that may explain other phenomena such as one's interests and vocational choice (creativity as explanans). Divergent thinking is an example of creativity as a psychological factor. In contrast, Weisberg (2006a) attempts to explain creativity in science, the arts, or invention as the product of problem solving that involves ordinary cognitive processes. Often, creativity theories lie somewhere in-between and try both to explain creativity itself and to use it as a factor for further explanations, for instance, Sternberg's investment theory of creativity (e.g., Sternberg, 2003). From this perspective, creativity is based on a decision to promote ideas that seem unpopular. 
Such decisions require specific intellectual skills, knowledge, thinking styles, personality, motivation, and a supporting environment. For Sternberg, creativity is "as much a decision about and an attitude toward life as it is a matter of ability" (2003, p. 109).

To apply creativity research to invention, a further distinction seems useful: earlyvs. late-cycle capacities (cf. Mumford, 2003). The early cycle refers to the production and selection of ideas, the late cycle to their implementation. This is the difference between inspiration vs. perspiration, addressed by Edison's remark: "Genius is one per cent inspiration, ninety-nine per cent perspiration" (1932). Similarly, Weisberg (2006a) distinguishes between problem finding and problem solving. However, even though almost all the time required for the invention process is dedicated to implementation, as a form of problem solving, the core and value of any invention is contained in its guiding idea. This is clearly expressed, for instance, by the German DABEI-Handbook (DABEI, 1987), written by some of the most impactful German inventors for their colleagues: four of ten steps of the invention process $(=40 \%)$ concern the preparation of finding and evaluating one's ideas, the invention process reaching from idea formation to the problem of finding a suitable successor for one's successful firm.

Discussion: Creativity as the core factor of inventive thinking would also make plausible the tendency of inventors to transgress domains (criterion D) and could provide us with a simple measure for success (E): the ideas produced, as to number and quality. However, from the perspective of creativity as divergent thinking, the role of knowledge remains unclear; the inventors' persistence would seem implausible: in case of severe challenges, for instance when a solution seems technologically infeasible, we would expect inventors to broaden their perspective and to easily switch to other matters. In reality, many top inventors are highly focused and stick to their original invention idea (Mieg, 2010). An answer might come from Sternberg's investment theory of creativity (2003): the inventor sticks to their idea because it represents a personal investment, relevant to one's life and social identity.

\subsection{Complex Problem Solving (cf. Fig. 2: CPS)}

Complex problem solving refers to the study of human behavior under complexity (Sternberg and Frensch, 1992; Frensch and Funke, 1995). A classical reference for this kind of research is the work on general problem solving by Newell and Simon (1972). However, this field of study arose from the increasing conviction that empirical results derived from studies using general, simplified tasks cannot be applied to more complex and ill-defined real-life problems. (Pretz et al., 2003, p. 9). According to Dörner (e.g. Dörner et al., 1983), problem situations can be considered as complex when they consist of many, partially connected variables that change dynamically and whose inter-relations are not transparent to the problem solver. Dörner and Schölkopf (1991, p. 219) define expertise in complex problem solving as 
coping with complex problem situations by being "a player who pays close attention to the relative configuration of the facts at a given time, aiming all the while at adapting current behaviour to the changing environment and constraints." Research on complex-problem solving today is sometimes addressed as naturalistic decision making (e.g., Zsambok and Klein, 1997).

Sometimes inventors are considered as expert problem solvers (Henderson, 2004a). As already mentioned, Weisberg (2006a) considers creativity in general as a form problem solving based on ordinary thinking. A perfect example of complex problem solving in invention is TRIZ, a toolbox for invention developed by Altschuller during the time of the former Soviet Union (cf. Orloff, 2006). The core idea is to detect seeming contradictions in the definition of a complex problem. Any type of contradiction can be matched with the set of solution principles that Altschuller derived from analysis of 9000 patents.

Discussion: From the perspective of complex problem solving, the role of knowledge seems clear (B), for instance when defined as expertise in complex problem solving above. Similarly, success criteria have been introduced, such as performance in complex, computer-simulated world scenarios (cf. Wolf and Mieg, 2010). Within this approach, persistence can be explained through the difference between the present state of work and the fixed, targeted solution (B). Central to the complex problem solving approach are heuristics, more or less general cognitive procedures, thus from this point of view inventors may be expected to cross domains in order to find solutions. Thus the transgression of domains is explained (D). However, the role of creativity remains undetermined (A), especially regarding early-cycle capacities (see 2.1). Idea formation or problem finding, respectively, generally transcend problem solving.

\subsection{Expertise (cf. Fig. 2: Ex)}

An option for explaining inventiveness is based on the psychology of expertise (Ericsson et al., 2006). In the last 80 years, expertise has been studied in a wide range of domains, ranging from chess and medical diagnostics to sports, music, and professional fields such as architecture or teaching. There is a set of several general findings. Requirements for the development of expertise are:

- A long period of individual training (deliberate practice), often 10 or more years, in order to become an expert.

- A strict domain specificity: Expertise in a domain cannot generally be transferred to problems in a neighboring domain.

- The development of expertise involves building up specific abstract and complex cognitive representations of the domain.

According to this view, top inventors are invention experts - or masters of invention. Indeed, as interviews with inventors revealed, successful inventors demonstrate a very strong motivation towards mastery (Henderson, 2004b). We 
also know that formal knowledge might the fundament of invention success, as the PatVal study revealed a very high level of academic education among inventors holding patents (Giuri et al., 2007, p. 1111). Moreover, the educational level correlates with the number of patents (Mariani and Romanelli, 2007). However, we know little about the core or content of the invention expertise. Friedhart Klix, a psychologist who for half a century studied human information processing, including the historical evolution of inventions (1993), concluded that inventiveness must be based on functional knowledge concerning technology and physics (Klix, 2005).

Discussion: The psychology of expertise represents a strong paradigm that can explain almost all explanation desiderata, in particular the roles of knowledge $(C)$, performance measures (E, cf. Ericsson, 1996), and persistence (B), the latter being related to deliberate practice and mastery as motivation. Ericsson $(1996,1999)$, the doyen of the psychology of expertise, even understands inventive creativity (A) as a characteristic of top experts in general. However, the expertise-approach is entirely unsuited to explaining inventors' disregard for domains. Experts are bound to their narrow domain, whereas inventors transgress domains (D).

\subsection{Entrepreneurship (cf. Fig. 2: Ent)}

The very well known inventors such Thomas Alva Edison (USA), Artur Fischer (Germany), or Nakamatsu Yoshirō (Japan), are or have also been entrepreneurs. In this vein, almost all European institutions supporting and advising inventors attempt to guide or even push inventors into entrepreneurship. However, many successful inventors employed in R\&D laboratories do not display any entrepreneurial ambition (Kassicieh et al., 1997). The desire among inventors, including independent inventors, to become an entrepreneur does not seem to be higher than in the general population.

Entrepreneurship requires the will and capability to establish and run a company. An entrepreneur takes risks in many sectors - financially and socially. Following the classical understanding by Schumpeter (1934/1911), entrepreneurs are innovators who deconstruct existing resource combinations in order to create new products, processes, or markets. From this point of view, an invention is only one input factor of innovation, as innovation implies the successful commercialization of an invention. Schumpeter called the work of entrepreneurs "creative destruction" (1942), as innovations replace or eliminate existing products, processes, or institutions.

Discussion: As Table 1 shows, understanding inventors as entrepreneurs would explain many of the desiderata. In particular, we would have a clear success criterion for inventions: success in the market. 
In the Lemelson-MIT workshop on invention, collaboration was considered so essential that one participant referred to inventors as intellectual bridges: "Because invention is so contextual, inventors can be thought of as intellectual bridges" (Lemelson-MIT Program, 2003, p. 19). An interpretation of 'inventors as intellectual bridges' is provided by the situated cognition approach (Clancey, 1997; Resnick et al., 1997; cf. Mieg, 2010). This approach examines inventors in the context of socially distributed work and socially shared knowledge. The concept of situated cognition is well-suited, for instance, to explain expertise in laboratory settings (e.g. Collins, 1985). From this perspective, becoming an inventor consists of a productive adaptation to a particular social and technological setting. One presupposition of situated cognition is that knowledge, theories, and language are tools or instruments that are socially shared. Accordingly, any invention is contextual, and innovation processes are best explained via networked expertise (Hakkarainen et al., 2004), the inventors being only one element.

Discussion: The situated cognition approach fulfils many of the theory requirements; for instance, domain transgression (D) could be explained by the embedding of experts in supra-domain networks. However, both the success criterion (E) and the persistence phenomenon (B) would lack a clear explanation from this point of view. The situated cognition approach is compatible with some approaches of organizational innovation (e.g., Hauschildt and Kirchmann, 2002). Generally speaking, this approach has more to do with innovation than invention.

\subsection{Possibility Filter (cf. Fig. 2: PF)}

An inventors-specific approach is provided by the concept of the "possibility filter" introduced by Robert Weber (2006): "In my interviews with inventors, and in the case of the Wrights, the inventors tend to view the world in an unusual way: through the eyes of possibility" (p. 5). The central element of this concept consists of the technological vision, in case of the Wright brothers, "the flight problem" of achieving powered and sustained heavier-than-air human flight. This technological vision defines a directed, cognitive space. The possibility filter "means that the inventor sees the world in a different way: not as it is but as it might be" (p. 6). Thus, the possibility filter leads to the:

- Selection and integration of new information (even failure);

- Generation of knowledge (via metacognition);

- Definition of developmental paths / trajectories (personally and technologically).

In particular, the possibility filter recognizes a common phenomenon reported in interviews (e.g., Brown, 1988), namely that inventors try to integrate or test any type of information from any source (technological, private, social...) in order to realize their technological vision. It is for that reason that analogy is an important heuristic in invention. The concept of the possibility filter makes it possible to 
describe invention both at the individual level and the socio-technological level, for instance, in the case of the historical perspective of the flight problem. Therefore, the possibility filter approach fits with higher-level models of the invention process (Lienhard, 2006; Arthur, 2009) that emphasize the general technology development as well the existence of a need or public purpose that initiates the invention process.

Discussion: The concept of the possibility filter implies a contextualization of invention, as the inventors provide technological visions. We can even say: the inventor becomes an instrument of the realization of his/her vision. Therefore, possibility filters are not domain-specific; rather a possibility filter creates its own domain. Inventors serve as 'domain pioneers.' Thus, the possibility filter approach explains many of the phenomena related to inventors (such as their persistence that - from this point of view - is caused by the dominance of and fixation upon the original idea.

\begin{tabular}{|c|c|c|c|c|c|c|}
\hline Approach & $\begin{array}{l}\text { Concept of } \\
\text { inventor }\end{array}$ & $\begin{array}{c}\text { Explained } \\
\text { issues }(A-E)^{*}\end{array}$ & $\begin{array}{c}\text { Level of } \\
\text { explanation }\end{array}$ & $\begin{array}{c}\text { Studies } \\
\text { (examples) }\end{array}$ & $\begin{array}{c}\text { From } \\
\text { invention to } \\
\text { innovation }\end{array}$ & Open issues \\
\hline Creativity & $\begin{array}{l}\text { Super-- } \\
\text { creative } \\
\text { person }\end{array}$ & $\begin{array}{c}\mathrm{A}++, \mathrm{B} ?, \mathrm{C} ?, \mathrm{D}+ \\
\text { E+ (ideas) }\end{array}$ & Individual & $\begin{array}{c}\text { Sternberg; } \\
\text { Mumford; } \\
\text { Lemelson-MIT }\end{array}$ & Invention & $\begin{array}{l}\text { C: invention } \\
\text { focus? }\end{array}$ \\
\hline $\begin{array}{l}\text { Complex- } \\
\text { Problem- } \\
\text { Solving }\end{array}$ & $\begin{array}{l}\text { Top problem } \\
\text { solver }\end{array}$ & $\begin{array}{l}\text { A?, B+, C+, D++ } \\
\text { (heuristics), E+ }\end{array}$ & Individual & $\begin{array}{c}\text { TRIZ; Wolf \& } \\
\text { Mieg; Weisberg }\end{array}$ & Both & A: creativity? \\
\hline Expertise & $\begin{array}{l}\text { Expert in } \\
\text { invention / } \\
\text { inventive } \\
\text { expert }\end{array}$ & $\begin{array}{c}\mathrm{A}+, \mathrm{B}+, \mathrm{C}++ \\
\text { (expertise), } \mathrm{D}-, \\
\mathrm{E}+\end{array}$ & Individual & $\begin{array}{c}\text { (Henderson, } \\
\text { Hoisl) / } \\
\text { (Ericsson) }\end{array}$ & Both & $\begin{array}{l}\text { D: domain- } \\
\text { specificity? }\end{array}$ \\
\hline $\begin{array}{l}\text { Entre- } \\
\text { preneur- } \\
\text { ship }\end{array}$ & $\begin{array}{c}\text { (Techno- } \\
\text { logical) } \\
\text { entrepreneur }\end{array}$ & $\begin{array}{l}\mathrm{A}+, \mathrm{B} ?, \mathrm{C}+, \mathrm{D}+ \\
\mathrm{E}++(\text { economic } \\
\text { success })\end{array}$ & $\begin{array}{l}\text { Individual } \\
\text { viewed from } \\
\text { the company } \\
\text { level }\end{array}$ & $\begin{array}{c}\text { PatVal; } \\
\text { Henderson }\end{array}$ & Innovation & $\begin{array}{c}\text { Few } \\
\text { inventors are } \\
\text { also entre- } \\
\text { preneurs. }\end{array}$ \\
\hline $\begin{array}{l}\text { Situated } \\
\text { Cognition }\end{array}$ & $\begin{array}{l}\text { "Intellectual } \\
\text { bridge" }\end{array}$ & $\begin{array}{l}\mathrm{A}+, \mathrm{B} ?, \mathrm{C}+, \mathrm{D}+ \\
\text { (network), E? }\end{array}$ & Networks & $\begin{array}{l}\text { Hakkarainen et } \\
\text { al. (2004) }\end{array}$ & Innovation & $\begin{array}{l}\text { This is a } \\
\text { theory of } \\
\text { innovation } \\
\text { (based on the } \\
\text { expertise- } \\
\text { approach). }\end{array}$ \\
\hline $\begin{array}{l}\text { Possibility } \\
\text { Filter }\end{array}$ & $\begin{array}{l}\text { Instrument } \\
\text { of socio- } \\
\text { technological } \\
\text { development }\end{array}$ & $\begin{array}{c}\text { A+, B++, (idea- } \\
\text { fixation), C+, } \\
\text { D+, E- }\end{array}$ & $\begin{array}{l}\text { Socio-technical } \\
\text { system }\end{array}$ & Weber, Arthur? & Invention & E: success? \\
\hline
\end{tabular}

Table 1: Theory approaches to invention.

* A: Important role of creativity, B: Persistence, C: Important role of knowledge, D: Transgression of domains, E: Success criterion; +: can be explained; ++: is basic to this approach; ?: unclear; -: the approach implies the contrary.

Table 1 summarizes the introduced research approaches to invention. It also indicates the level of explanation (individual or supra-individual) and the focus in the innovation process (on invention specifically or on innovation in general). In 
addition, Figure 2 (bottom) shows the positioning of the six approaches. The arrows hint at two of the many theory shifts in this field. For instance, Hakkarainen et al. (2004) developed the "networked expertise" approach, moving out of a general expertise research framework. Their approach is of a situated cognition type and represents the kind of system seen in Finland for understanding and implementing innovations. The second arrow, from CPS to PF, represents the move by Weber $(1996,2006)$ from intense research on inventors' heuristics to his possibility filter approach.

\section{The Model}

Figure 3 displays the two-path process model of invention. It focuses on the individual inventor, and is intended to explain individual inventors' potential for success. Organizational or technological conditions are defined as boundary conditions or external inputs. The model basically consists of two processes or paths (dashed lines), two necessary conditions (creativity, emotional stability), and seven supporting conditions (arrows), conceptualized as on/off conditions (0/1).

The two main paths are: a problem-solving path, and an idea-driven one, each with a feedback loop. Problem-solving may temporarily form part of the idea-driven path. Both paths involve the application of heuristics. The idea-driven path has a longer time-perspective than the problem-solving path and includes long-term learning in feedback loops (technology, markets, or organizations). Therefore, the present takes much longer for the idea-driven paths, whereas for the problem-solving path all previously solved problems lie in the past.

Our core assumption is that invention is about technology and technological development. Thus, knowledge comes into play, and creativity is limited to technology. The further assumptions with regard to the research desiderata are:

A: Role of creativity: Creativity is understood as an initial, necessary condition, not as a success factor. In inventors, a further increased creativity does not seem conducive to successful invention (Braun et al., 2009);

B: Role of knowledge: Both technical-functional knowledge and a higher education in science \& technology are considered as factors that support the success of inventors;

C: Persistence: Persistence in inventors can be explained by their high tolerance for frustration (emotional stability), often in combination with a fixed idea;

D: Transgression of domains: This can be explained by the use of heuristics;

E: Success indicator: There is a series of success criteria, starting with patents as the most general one. Then comes marketed patents (i.e., the number of patents that are valued by the market). Finally, we have invention efficiency (IE) as a measure relating outcome to effort (Wolf and Mieg, 2010).

The model distinguishes initial necessary conditions and supporting conditions. The two necessary conditions (i.e., starting requirements) for any inventor are: a high 
level of creativity and a high level of emotional stability (cf. Braun et al., 2009). The seven supporting conditions (arrows), conceptualized as on/off conditions (0/1). supporting conditions for successful inventors are:

1) Technical-functional knowledge (Klix, 2005);

2) Higher education in science \& technology (Giuri et al., 2007; Mariani and Romanelli, 2007);

3) Metacognition: deliberate control of divergent and convergent thinking (Wolf and Mieg, 2010);

4) Patenting know-how: inventor themselves, or their firm (Mieg et al., 2010);

5) Organizational support (e.g. Hauschildt and Kirchmann, 2002);

6) Reworking prototypes (Fischer, 1987);

7) Feedback in one or more arena(s):

- Technology (Lienhard, 2006; Arthur, 2009);

- The market (cf. DABEI, 1987);

- The organization (Hoisl, 2007; Gambardella et al., 2007; Blind et al., 2006);

The focus in one or more of the arenas may lead to different sorts of inventors, namely to:

- Inventors who are dedicated to long-term technological development, such as the Wright brothers;

- Inventors who invent for their customers, such as the firm IDE0;

- Inventors who build up different forms of local and transnational, private, and public invention organizations, as in the case of Ludwig Bölkow, the father of Airbus.

The supporting conditions are considered as binary on/off conditions, which may be fulfilled or not. Therefore, these conditions cannot over-compensate one another; an extraordinarily increase in one condition (e.g., higher education) cannot compensate the lack in more than one other condition.

Further propositions or assumptions of this two-path process model are:

1) Invention is idea-driven and/or problem-driven. Idea-driven means: a big idea becomes reality (e.g., "to fly"). Problem-driven means: an urgent problem has to be solved. An idea-driven invention defines a long-term project and may include problem-driven sub-processes.

2) Every invention project has two aspects: a resolution or problem-solving part (e.g., solve this puzzle) and a copyright part (it's my idea!). For employed inventors, the resolution part dominates; independent inventors are often very much concerned with the copyright issue.

3) The invention process is supported by several heuristics, primarily: sub-goaling, trial \& error, and analogy (cf. Mieg, 2010). We can further add intuitive heuristics (e.g., to sleep on a problem) and systematic heuristics (e.g., failure analysis of previous solutions; complete search of the space of possible solutions). The use of specific heuristics is not a success factor. 
4) In general, learning by inventors is confined to one arena (technology, markets, or organization), as the arenas have different logics and thus provide different optimization conditions.

5) The less productive an employed inventor, the more important is his/her organizational support. 
Journal of Science, Humanities and Arts

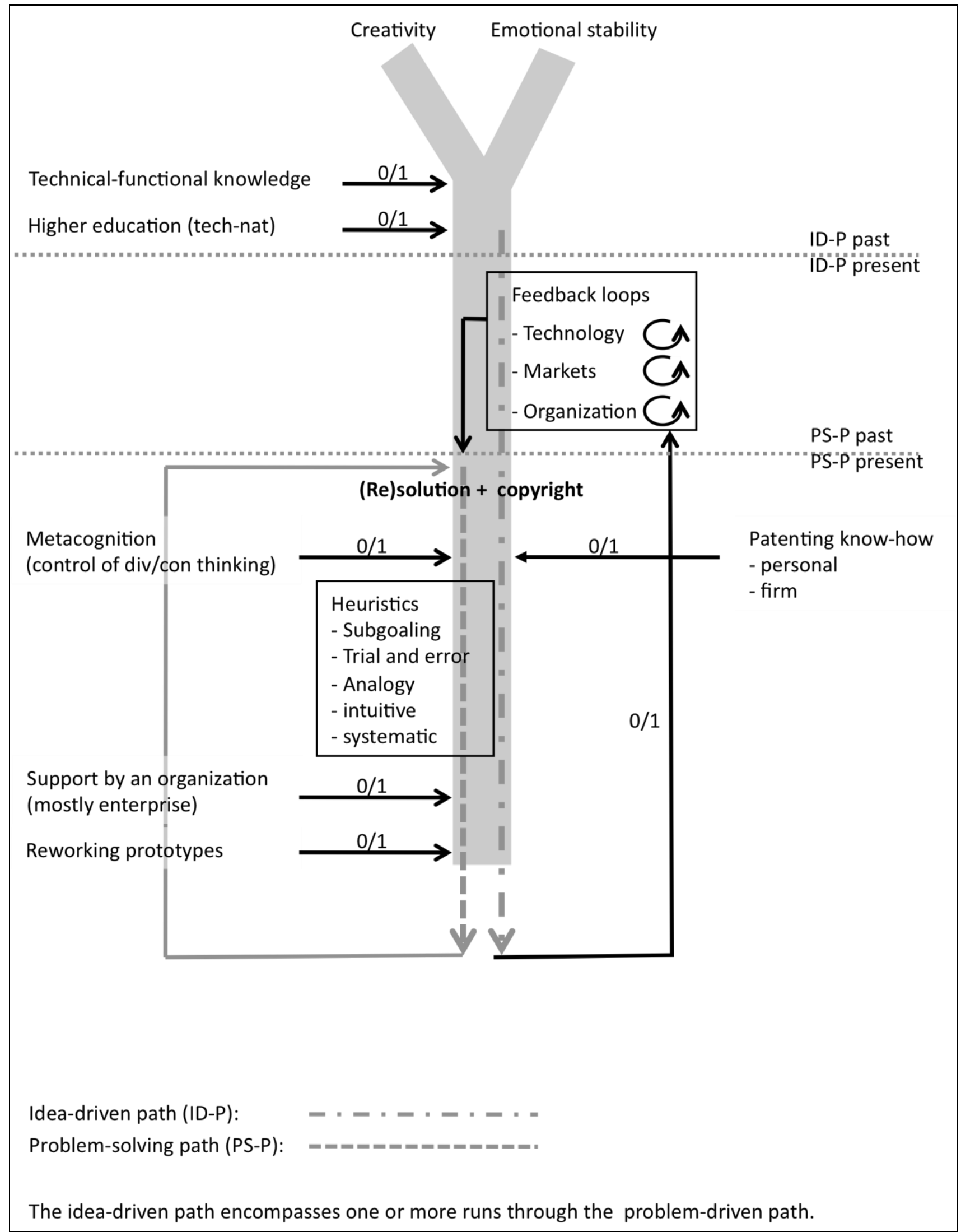


Journal of Science, Humanities and Arts

Figure 3 Two-path model of invention. Two necessary conditions: creativity and emotional stability. 0/1: Supporting conditions (on/off conditions). 


\section{Discussion}

The two-path model rests on the assumptions that the input of creativity to successful invention is limited and that invention is - in many cases - a distinctive phenomenon within innovation processes. Both assumptions can be questioned. Therefore, the discussion will touch the issue of creativity (4.2) as well as the role of inventors in innovation processes (4.3). We will start, however, with a general discussion on how the two-path-model meets the research desiderata (4.1).

\subsection{The Two-Path Model in the Light of the Research Desiderata}

The two-path model bases on empirical research conducted in the context of the Lemelson-MIT workshop (2003) "The Architecture of Invention," the PatVal study (Giuri et al., 2007), and studies on independent inventors (Dahlin et al., 2004; Lettl et al., 2009; Braun et al., 2009). It differs from other invention process models in that it is not normative and allows for non-technological context factors. For instance, the DABEI model is normative (DABEI, 1987), demanding a high degree of self-reflection by inventors. In contrast, the TRIZ model focuses on physicaltechnological matters (cf. Orloff, 2006). As mentioned, the inclusion of contextual factors is not a necessary feature, as there might exist theories about inventors that are more-or-less context-free. The two-path model is not a theory, as it arrays single conditions without ensuring semantic consistency among conditions and assumptions, as a true theory would require. However, the model is testable and should guide further research.

The two-path-model attempts to meet the research desiderata (see section 1.2), comprising two phenomena (persistence, transgression of domain) and three open issues (creativity, knowledge, success). In general, the model focuses on knowledge and motivation at the cost of creativity. Creativity is considered necessary for invention but not sufficient for inventive success. Knowledge appears in several components of the model: technical-functional knowledge; higher education; patenting know-how; heuristics. Furthermore, an increase in knowledge is implied by the several learning mechanisms that the model provides: in the many feedback loops as well as through the reworking of prototypes. Motivation is incorporated in the two (idea-driven and problem-solving) paths. Thus, the two-path model attempts to capitalize as much as possible from the benefits of the problem-solving and expertise approaches to invention (sections 2.2 and 2.3).

Our model supposes that successful inventions are commercialized in some way. Inventions are considered as part of the innovation process. The ideal measure would be the overall technological contribution of an invention, or: the breakthrough potential. For logical reasons, the breakthrough potential cannot be assessed in advance. The best available success measure for inventions is patents. However, it is obvious that we have to value patents. One common option is to assess patent-to-patent citations (e.g., Lettl et al., 2009). The two-path model 
suggests adding a form of market value, for instance, to enable investors to estimate or narrow down the economic revenues of the patents they hold (Wolf and Mieg, 2010). Then we obtain a measure for successful or even efficient inventors that includes both their number of patents and an economic valuation. Again, the economic value is not an ideal measure; it is the best available measure for how companies and other market players estimate the long-term potential of any invention.

\subsection{Creativity}

Creativity is the most important approach when it comes to explaining invention. Then, great inventions fall into the same class of phenomena as other extraordinary products of creativity, such as great works in literature and the arts or milestones in scientific discovery. The two-path model shifts the focus from creativity to technology. We believe that invention is more about improving technology than applying creativity. This focus allows us to study inventions from the perspectives of ordinary inventors employed in the R\&D departments of mid- or high-tech companies. We do not believe that any ordinary inventor makes a decision to invest in an idea in order to become different to other people - as we could derive from the investment theory of creativity (Sternberg, 2003). Rather, we see a motivation for solving problems by advancing technology. However, this remains an empirical question.

However, we do not support Weisberg's (2006a) interpretation of creativity as problem solving with regard to inventions. Many inventors are driven by a specific idea that does not need to directly respond to a specific personal or general problem. Therefore, we included an idea-driven path in the process model. Moreover, many inventors are very much concerned with the copyright problem and hide their ideas even at the risk of lacking contact with customers or access to companies and other supporting structures. Turning an idea into a product indeed requires problem solving, and involves - as emphasized in the Lemelson-MIT workshop (Perkins, 2004, p. 40) - the transgression of domains. In this context, Weber provided much evidence for the use of heuristics in the invention process (Weber et al., 1990; Weber, 1992a\&b; Perkins and Weber, 1992). This has been accounted for within the two-path model.

A final word on the concept of creativity: One may be tempted to use the creativity concept to explain novelty. However, if novelty represents discontinuity, then creativity might turn out a pseudo-explanation and is just an indicator for a lack of any explanation, or another word for chance. Consequently, the problem-solving approach to creativity (section 2.2; Weisberg, 2006a) does not really take into account the building of the technological idea (i.e., finding and defining the original problem to be solved). If we try to view the building of the technological idea from the problem-solving approach to creativity, then the agent of problem solving might change, and we would have to turn to society or mankind as the original "problem 
solvers" for great ideas such as human flight. To avoid such conceptual stress, an approach like Weber's possibility filter (2006) seems more adequate for explaining inventions: They are born out of the possibilities provided by the contemporary technological state-of-the-art.

\subsection{The Role of Inventors in the Innovation Process}

In general, invention is only one step in an innovation process. Most inventions are based on collaborative work. The authors of the PatVal study even argue that collaboration is severely under-estimated (Giuri et al., 2007) when using patent data. No wonder that company size is the best predictor for the productivity of employed inventors (Blind et al., 2006; Gambardella et al., 2007). Moreover, collaboration is not confined to a firm. Collaboration occurs within networks of inventors or researchers, and there is the collaboration in a weak sense of a technological field: all the inventors, firms, and teams working on a group of related problems. This is why Arthur (2009) hints to the fact that no invention happens "out of the blue" but is carried on by a public need and embedded in a technological status quo. In the same vein, a possibility filter functions as a trajectory for technological development.

Even though innovation is a collaborative effort, we stick to the focus on individual inventors as a distinct phenomenon of the innovation process. There are at least three, partly interrelated reasons. Firstly, the phenomenon of independent inventors (Dahlin et al., 2004; Lettl et al., 2009; Braun et al., 2009). Independent inventors still make a substantial contribution to the stock of high-potential patents. Independent inventors also work as professionals in a similar manner to physicians or accountants, and there is no reason to deny them the status of a professional group. Secondly, the phenomenon of highly skewed distribution of productivity among inventors (e.g., Ernst et al., 2000; Huber, 1998; Narin and Breitzman, 1995). A company may depend on the extraordinary patenting productivity of just a few of its many R\&D employees. Although supported by contextual factors, this increased productivity can be considered a personal characteristic of individual inventors, a fact that makes it worth conducting research on this group. Thirdly, the phenomenon of increasing returns from the individual stock of inventing knowledge-in other words, a growing invention competence. As Weisberg (2006b) showed, the '10-year-rule' also applies to inventors: It takes a long period of "deliberate practice" (Ericsson et al., 1993) to become an expert inventor similarly to experts in other domains.

What, then, is the role of the inventor in the innovation process? In the context of the Situated Cognition approach (section 2.5), inventors were termed "intellectual bridges" (Lemelson-MIT Program, 2003, p. 19) due to the importance of collaboration in invention. This would also hold from the perspective of the twopath model, as we can claim: Inventors are intellectual bridges to technology; they are a necessary component of technological change. 
Journal of Science, Humanities and Arts 
References

Åstebro, T., Jeffrey, S. A., \& Adomdza, G. K. (2007). Inventor perseverance after being told to quit: The role of cognitive biases. Journal of Behavioral Decision Making, 20, 253-272.

Arthur, W. B. (2009). The nature of technology: What it is and how it evolves. New York: Free Press.

Blind, K., Edler, J., Frietsch, R., \& Schmoch, U. (2006). Motives to patent: Empirical evidence from Germany. Research Policy, 35, 655-672.

Braun, A., Mieg, H. A., \& Neyer, F. J. (2009). Sind Erfinder anders als es die Kreativitätsforschung erwarten lässt? Wirtschaftspsychologie, 11(1), 69-79. (English version: Mieg, H. A., Bedenk, S., Braun, A., \& Neyer, F. J. (2012). How emotional stability and openness to experience support invention: A study with German independent inventors. Creativity Research Journal, 24(2-3), 200-207.

Brown, K. A. (1988). Inventors at work: Interviews with 16 notable American inventors. Redmond: Tempus/Microsoft.

Clancey, W. J. (1997). Situated cognition. Cambridge, UK: Cambridge University Press.

Collins, H. M. (1985). Changing order. London: Sage.

DABEI (Deutsche Aktionsgemeinschaft Bildung - Erfindung - Innovation) (Eds.) (1987). DABEI-Handbuch für Erfinder und Unternehmer [DABEI-handbook for inventors and entrepreneurs]. Düsseldorf: VDI-Verlag.

Dahlin, K., Taylor, M., \& Fichman, M. (2004). Today's Edisons or weekend hobbyists: Technical merit and success of inventions by independent inventors. Research Policy, 33, 1167-1183.

Dörner, D., \& Schölkopf, J. (1991). Controlling complex systems; or, expertise as "grandmother's know-how." In K. A. Ericsson \& J. Smith (Eds.), Towards a general theory of expertise: Prospects and limits (pp. 218-239). New York: Cambridge University Press.

Dörner, D., Kreuzig, H. W., Reither, F., \& Stäudel, T. (Eds.) (1983). Lohhausen: Vom Umgang mit Unbestimmtheit und Komplexität [Lohhausen: On dealing with uncertainty and complexity]. Bern: Huber.

Duncker, K. (1935). Zur Psychologie des produktiven Denkens [The psychology of productive thinking]. Berlin: Springer.

Ericsson, K. A. (1996). The acquisition of expert performance: An introduction to some of the issues. In K. A. Ericsson (Ed.), The road to excellence: The acquisition of expert performance in the arts and sciences, sports, and games (pp. 1-59). Mahwah, NJ: Lawrence Erlbaum.

Ericsson, K. A. (1999). Creative expertise as superior reproducible performance: Innovative and flexible aspects of expert performance (Commentaries). Psychological Inquiry, 10(4), 329-361. 
Ericsson, K. A., Krampe, R. T., \& Tesch-Römer, C. (1993). The role of deliberate practice in the acquisition of expert performance. Psychological Review, 100(3), 363- 406.

Ericsson, K. A., Charness, N., Feltovich, P., \& Hoffman, R. R. (Eds.). (2006). The Cambridge handbook of expertise and expert performance. Cambridge, UK: Cambridge University Press.

Ernst, H., Lepties, C., \& Vitt, J. (2000). Inventors are not alike: The distribution of patenting output among industrial R \& D personnel. IEEE Transactions on Engineering Management, 47(2), 184-199.

Feltovich, P. J., Prietula, M. J., \& Ericsson, K. A. (2006). Studies of expertise from psychological perspectives. In K. A. Ericsson, N. Charness, P. Feltovich \& R. R. Hoffman (Eds.), The Cambridge handbook of expertise and expert performance (pp. 41-67). Cambridge, UK: Cambridge University Press.

Fischer, A. (1987). Erfolg ist das Produkt stetiger Mehrleistung [Success is the result of permanent supererogation]. In DABEI (Eds.), DABEI-Handbuch für Erfinder und Unternehmer (pp. 390-392). Düsseldorf: VDI-Verlag.

Frensch, P. A., \& Funke, J. (Eds.) (1995). Complex problem solving: The European perspective. Hillsdale, NJ: Lawrence Erlbaum.

Gambardella, A., Giuriy, P., \& Luzzi, A. (2007). The market for patents in Europe. Research Policy, 36, 1163-1183.

Giuri, P., Mariani, M., Brusoni, S., Crespi, G., Francoz, D., Gambardella, A., GarciaFontes, W., Geunac, A., Gonzales, R., Harhoff, D., Hoisl, K., Le Bas, C., Luzzi, A., Magazzini, L., Nesta, L., Nomaler, O., Palomeras, N., Patel, P., Romanelli, M., \& Verspagen, B. (2007). Inventors and invention processes in Europe: Results from the PatVal-EU survey. Research Policy, 36, 1107-1127.

Hakkarainen, K., Palonen, T., Paavola, S., \& Lehtinen, E. (2004). Communities of networked expertise: Educational and professional perspectives. Amsterdam: Elsevier.

Hauschildt, J., \& Kirchmann, E. (2002). Teamwork for innovation - the 'troika' of promotors. R\&D Management, 31(1), 41-49.

Hellström, T., Hellström, C., \& Berglund, H. (2002). The innovation self: Exploring self among a group of technological innovators. Journal of Managerial Psychology, 17(4), 267-286.

Henderson, S. J. (2004a). Inventors: The ordinary genius next door. In R. J. Sternberg, E. L. Grigorenko, \& J. L. Singer (Eds.), Creativity: From potential to realization (pp. 103-125). Washington, DC: American Psychology Association.

Henderson, S. J. (2004b). Product inventors and creativity: The finer dimensions of enjoyment. Creativity Research Journal, 16, 293-312.

Hoisl, K. (2007). Tracing mobile inventors: The causality between inventor mobility and inventor productivity. Research Policy, 36, 619-636.

Huber, J. C. (1998). Invention and inventivity is a random, Poisson process: A potential guide to analysis of general creativity. Creativity Research Journal, 11(3), 231-241.

Kassicieh, S. K., Radosevich, H. R., \& Banbury, C. M. (1997). Using attitudinal, situational, and personal characteristics variables to predict future 
entrepreneurs from national laboratory inventors. IEEE Transactions on Engineering Management, 44(3), 248-257.

King, L. A., McKee Walker, L., \& Broyles, S. J. (1996). Creativity and the five-factor model. Journal of Research in Personality, 30, 189-203.

Kirton, M. J. (1976). Adaptors and innovators: A description and a measure. Journal of Applied Psychology, 61, 622-629.

Kirton, M. J. (1994). Adaptors and innovators: Styles of creativity and problem solving. New York: Routledge.

Klix, F. (1993). Erwachendes Denken [Awakening thinking]. Heidelberg: Spektrum.

Klix, F. (2005). Telephone interview (with Harald A. Mieg).

Kriegesmann, B., Kerka, F., \& Kley, T. (2007). Fehlerkulturen und Innovationserfolg [A culture of failure and innovation success]: Eine vergleichende empirische Analyse. Zeitschrift für Personalforschung, 20(2), 141-159.

Lemelson-MIT Program (2003). The architecture of invention (Report of the workshop held in August 2003). Boston: School of Engineering, Massachusetts Institute of Technology. [available online: https://www.scribd.com/document/79070457/Architecture ]

Lettl, C., Rost. K., \& von Wartburg, I. (2009). Why are some independent inventors 'heroes' and others 'hobbyists'? The moderating role of technological diversity and specialization. Research Policy, 38, 243-254.

Lienhard, J. H. (2006). How inventions begins. Oxford: Oxford University Press.

Lotka, A. J. (1926). The frequency distribution of scientific productivity. Journal of the Washington Academy of Science, 16, 317-323.

Mariani, M., \& Romanelli, M. (2007). "Stacking" and "picking" inventions: The patenting behavior of European inventors. Research Policy, 36, 1128-1142.

McCrae, R. R. (1987). Creativity, divergent thinking, and openness to experience. Journal of Personality and Social Psychology, 52(6), 1258-1265.

Mieg, H. A. (1993). Computers as experts? On the non-existence of expert systems. Frankfurt/New York: Lang.

Mieg, H. A. (2010). Focused cognition: Information integration and complex problem solving by top inventors. In K. L. Mosier \& U. M. Fischer (Eds.), Informed by knowledge: Expert performance in complex situations (pp. 41-54). London: Taylor \& Francis.

Mieg, H. A., Hoffmann, C., \& Spars, G. (2010). Evaluierung der volkswirtschaftlichen Bedeutung von Einzelerfindungen und deren Umsetzungspotential am Standort Berlin [Inventors in Berlin, a report to the Berlin Senate]. Studie im Auftrag der Senatsverwaltung für Wirtschaft, Technologie und Frauen, Bericht.

Mumford, M. D. (2003). Where have we been, where are we going? Taking stock in Creativity Research. Creativity Research Journal, 15(2-3), 107-120.

Narin F., \& Breitzman, A. (1995). Inventive productivity. Research Policy, 24, $507-$ 519.

Newell, A. (1985). Duncker on thinking: An inquiry into progress on cognition. In S. Koch and D. E. Leary (Eds.), A century of psychology as a science (pp. 392-419). Oxford: Oxford University Press. 
Newell, A., \& Simon, H. A. (1972). Human problem solving. Englewood Cliffs, NJ: Prentice-Hall.

Orloff, M. A. (2006). Inventive thinking through TRIZ (2nd ed.). Berlin: Springer.

Perkins, D. N. (2004). Mapping the inventive mind. In Lemelson-MIT Program (2004). Invention: Enhancing inventiveness for quality of life, competitiveness, and sustainability (report, pp. 37-45). Boston: School of Engineering, Massachusetts Institute of Technology.

Perkins, D. N., \& Weber, R. J. (1992). Conclusion: Effable invention. In R. J. Weber \& D.N. Perkins (Eds.). Inventive minds: Creativity in technology (pp. 317-336). New York: Oxford University Press.

Price, D. J. S. (1963). Little science, big science. New York: Columbia University Press.

Resnick, B. L., Pontecorvo, C., \& Säljö, R. (1997). Discourse, tools, and reasoning. In B. L. Resnick, R. Säljö, C. Pontecorvo, \& B. Burge (eds.), Discourse, tools, and reasoning: Essays on situated cognition (pp. 1-20). Berlin: Springer.

Rossman, J. (1964). Industrial creativity: The psychology of the inventor. New Hyde Park, NY: University Books.

Schumpeter, J. A. (1934). The theory of eceonomic development (translated by R Opie). New Brunswick/London: Transaction. (German original in 1911: Theorie der wirtschaftlichen Entwicklung).

Schumpeter, J. (1942). Capitalism, socialism, and democracy. New York: Harper and Row.

Simonton, D. K. (1988). Scientific genius: A psychology of science. Cambridge: Cambridge University Press.

Sternberg, R. J. (2003). Wisdom, intelligence, and creativity synthesized. New York: Cambridge University Press.

Sternberg, R. J., \& Frensch, P. A. (1992). On being an expert: A cost-benefit analysis. In R. R. Hoffman (Ed.), The psychology of expertise (pp. 191-203). New York: Springer.

Weber, R. J. (1992a). Forks, phonographs, and hot air balloons: A field guide to inventive thinking. New York: Oxford University Press.

Weber, R. J. (1992b). Stone age knife to Swiss army knife: An invention prototype. In R. J. Weber \& D. N. Perkins (Eds.). Inventive minds: Creativity in technology (pp. 217-237). New York: Oxford University Press.

Weber, R. J. (1996). Toward a language of invention and synthetic thinking. Creativity Research Journal, 9(4), 353364.

Weber, R. J. (2006). The Wright Brothers and the heuristics of invention. Paper presented at the conference "Expertise in context", Berlin 26-28 July.

Weber, R. J., Moder, C. L., \& Solie, J. B. (1990). Invention heuristics and mental processes underlying the development of a patent for the application of herbicides. New Ideas in Psychology, 8(3), 341-336.

Weisberg, R. W. (2006a). Creativity: Understanding innovation in problem solving, science, invention, and the arts. Hoboken, $\mathrm{NJ}$ : Wiley.

Weisberg, R. W. (2006b). Modes of expertise in creative thinking. In K. A. Ericsson, N. Charness, P. Feltovich, \& R. R. Hoffman (Eds.), The Cambridge handbook of 
expertise and expert performance (pp. 761-787). Cambridge, UK: Cambridge University Press.

West, M. A. (2002). Sparkling fountains or stagnant ponds: An integrative model of creativity and innovation implementation in work groups. Applied Psychology, 51(3), 355-424.

Wolf, K., \& Mieg, H. A. (2010). Cognitive determinants of the success of inventors: Complex problem solving and deliberate use of divergent and convergent thinking. European Journal of Cognitive Psychology, 22(3), 443-462.

Zayer, E. (2007). Verspätete Projektabbrüche in F\&E: Eine verhaltensorientierte Analyse. Wiesbaden: Deutscher Universitäts-Verlag; GWV Fachverlage GmbH. Zsambok, C. E., \& Klein, G. (Eds.). (1997). Naturalistic decision making. Mahwah, NJ: Lawrence Erlbaum Associates. 